\title{
Populism, Media, and Misinformation in Latin America
}

\author{
Ignacio Siles, ignacio.siles@ucr.ac.cr \\ Larissa Tristán, larissa.tristan_j@ucr.ac.cr \\ Carolina Carazo, carolina.carazo@ucr.ac.cr \\ School of Communication \\ Universidad de Costa Rica \\ San José, Costa Rica
}

Forthcoming in Howard Tumber and Silvio Waisbord (Eds.) (2021). The Routledge Companion to Media Misinformation and Populism. London: Routledge. 


\section{Populism, Media, and Misinformation in Latin America}

Latin America has had a long, complex, and complicated relationship with populism. Political figures in the region are usually considered some of the very founders or most iconic representatives of populism (De la Torre, 2000), starting with classic forms of populism (Lázaro Cárdenas in Mexico, Juan Domingo Perón in Argentina, and Getúlio Vargas in Brazil), followed by so-called neo-populisms (Alberto Fujimori in Peru, Carlos Salinas de Gortari in Mexico, Fernando Collor de Melo in Brazil, and Carlos Menem in Argentina), and more recent populist figures of the 21st century, such as Hugo Chávez in Venezuela, Evo Morales in Bolivia, and Rafael Correa in Ecuador. There is even an entire subfield of studies devoted specifically to Latin American populism (Retamozo, 2017).

Historically, media systems have played a key role in shaping Latin American populism. As Weyland (2001) argued about the region, "through television populist leaders reach[ed] their followers directly and establish[ed] quasi-personal contact with millions of people simultaneously. While radio played a similar role for classical populists, television [was] more powerful in projecting charismatic leadership" (p. 16). This chapter discusses the particular relationship between populism, media, and misinformation in Latin America. We envision populism as a "media and communication phenomenon" (Waisbord, 2019) and thus examine the role of social media platforms in shaping populism and issues of misinformation in the region. Our analysis proceeds in four steps.

First, we briefly situate the study of populism and media in Latin America within a broader history. To this end, we discuss the links between populism and specific styles of political communication that emerged at the turn of the century. Second, we focus on how scholars have analyzed the significance of digital media in shaping populism in Latin America. 
We thus examine the regional specificities of what some scholars have labeled as "populism 2.0." Third, we assess how researchers have analyzed specifically the "elective affinity" (Waisbord, 2018a) between post-truth (in the form of its most symptomatic expression, so-called "fake news") and populism in academic literature. Our discussion draws on an analysis of the theoretical preferences, methodological approaches, and conclusions of this body of work. We also review major findings that come from regional surveys on media use, misinformation, and populism. We argue that a consideration of the "elective affinity" between post-truth and populism in the case of Latin America requires assessing the significance of religion and its associated forms of polarization and messianic authority. We conclude by summarizing the main contributions of scholarly literature on these issues and by suggesting new avenues for research on this topic.

\section{Media and Populism at the Turn of Century}

In the beginning of the new century, the relationship between populism and media in Latin America found an expression in two parallel processes, which Waisbord (2014) summarizes with precision: on the one hand, "the politization of the media" and, on the other, "the mediatization of politics" (p. 17). ${ }^{1}$ The former process refers to important attempts to reform media systems in many countries of Latin America. Such attempts took place in at least 11 countries of the region during the 2000s decade (Guevara, 2012). Waisbord (2014) considers some of these reforms - typically anchored in the idea of rupture in prevailing media systemsas populist in that they expressed "a statist vision of media systems aimed at strengthening the communicational power of the presidency and based on the logic of 'friend/enemy' as the

\footnotetext{
${ }^{1}$ All translations from quotes in languages other than English are our own.
} 
organizing principle" (p. 29). Some have not hesitated to label the disputes that surrounded these reforms as "media wars" (Guevara, 2012).

The latter process - the mediatization of politics — centers instead on specific styles or forms of political communication that took shape throughout the decade. It focuses on populism as a rhetoric, a "strategy and a discursive frame" (Waisbord, 2019, 222). Newly elected presidents in Latin American countries turned to the media to "genuinely and 'directly' connect with 'the people"' (Moffitt, 2019, 30). Because of the centrality of media in their political projects, Rincón (2008) referred to these figures as "los tele-presidentes" (the tele-presidents). Examples were found at both ends of the political spectrum. Hugo Chávez launched his television show Aló, Presidente in 1999, arguably the most iconic piece of political communication of the following decade in the region; Álvaro Uribe aired his Consejos Comunales starting in 2002 and thus turned "the people into his main communication weapon" (de Vengoechea, 2008, 135); and Luiz Inácio Lula offered hundreds of radio interviews on a variety of topics in Café com o Presidente, created in 2003. These shows blended specific audiovisual formats and certain forms of political communication. In many ways, they sought to overcome a crisis of political representation well seated in the region during the 1990 s.

The trademark of los tele-presidentes was establishing a form of "live" communication that Guevara (2012) summarizes thusly: "The aim [was] to involve all citizens in the government decision-making and problem-solving processes, thereby claiming to make communication a new tool for public management" (p. 118). For Rincón $(2008,9)$, the "communications kit" of politicians during the decade also included the need to perform a presidential posture (in addition to actually having being elected), to "govern for a spectator/viewer rather than for a citizen," to convey an affective national project, to "turn the people into an ideological and aesthetic guide 
and inspiration," and to always be present in the media. Implementing this "kit" also required incorporating aesthetic and formal elements of various genres (including advertising, talk shows, reality television, and news broadcasting) (Guevara, 2012; Rincón, 2008).

The rise of this form of political communication gathered the attention of scholars from the region and abroad (Berjaud, 2016; Boas, 2005; De la Torre, 2017). References to populism in this body of work range from latent to explicit. Rincón (2008) is among those who linked populism and the communication styles of los tele-presidentes in the most straightforward way:

Political parties were over and a formula was created that mixed the media hero (a charismatic personality) with populism (direct welfare and social redemption of the poor) and liberal economy elitism (unrestricted support for businessmen and new riches). This new system is based on the leader who governs through a form of light and entertainment-like authoritarianism; which enacts a live (en directo) democracy, without means or intermediaries; which thinks in local perspective. (p. 6)

Most of these television and radio programs did not survive the end of the 2000s decade. With the arrival of a new decade, both the attempts to communicate "directly" with "the people" and the social concerns generated by such forms of communication translated to media platforms that were starting to gain traction in the region: social media. This process unfolded as new populist politicians took office. Compared to their predecessors, Latin American political leaders of the 2010s decade were relatively less charismatic. Despite the attempts, Nicolás Maduro and Dilma Rousseff had difficulties in reproducing the media success of Hugo Chávez and Luiz Inácio Lula, respectively. Yet, they sought to maintain a form of populist authority in which social media played a central role. 


\section{The "Social Media-Populism Nexus"}

Social media platforms became a favorite object of study in Latin America in the early years of the 2010s decade (Siles, Espinoza, \& Méndez, 2019). In this context, scholars have focused on the significance of social media in shaping populist practices and discourses. Some authors have seen the rise of such platforms as an opportunity for reinvigorating the populist communications kit that prevailed in the previous decade in Latin America-notably "top-down" styles of communication that hailed presidential figures (Waisbord, 2014). Scholars have coined terms such as "technopopulism" (De la Torre, 2013) or "populism 2.0" to refer to this "social media-populism nexus” (Moffitt, 2019, 30).

It is not uncommon to find mentions in scholarly literature of the role of social media in enabling a "new populist era" (Mudde, 2016, 29). Several features of social media platforms are typically envisioned as opportunities (or, more precisely, "affordances") for populist communication. In these accounts, social media would be ideal for exploiting and empowering populism's historical penchants. For example, Waisbord and Amado (2017) note that, “In principle, Twitter facilitates the kind of horizontal, interactive communication praised by populist rhetoric. It offers a flattened communication structure in contrast to the top-down structure of the legacy media. It is suitable for unmediated exchanges between politicians and citizens" (p. 1332). As Moffitt $(2019,31)$ notes, these ideas rely on the premise that social media allow presidents to be "in touch with the people" in a "multi-directional" way. It could also be suggested that social media is ideal for "reinforcing in-group mentality against outgroups [...] [and] cement[ing] homophilic communication and identity-centered communication" (Waisbord, 2019, 229). It is perhaps for all these reasons that presidents in Latin America typically 
associated with populism have tended to be more active on social media platforms like Twitter than those who are not (Waisbord \& Amado, 2017).

Populist communications on social media are characterized by specific features. Using statistical analysis of Twitter use and content analysis of presidents' tweets in Latin America, Waisbord and Amado (2017) showed that presidents who have adopted this form of communication tend to use Twitter to gain visibility, reinforce presidential figures, comment on a range of issues in a fast manner, "throw rhetorical punches at political rivals," and "spread presidential messages without tough questions, dissident views, and open exchanges with citizens" (p. 1342). Farias (2018) also employed content analysis to compare the discourse of both Nicolás Maduro and the Venezuelan opposition on Twitter. She argued that Maduro continued with his predecessor style in using a "discursive communications [discourse] predominantly populist [that reflects] an understanding of politics as a zero-sum game" (p. 89).

The media has been a typical target of populist discourse. Here, social media is seen as an ideal communication outlet because of its independence from "the system" that is typically opposed in populist discourse (De la Torre, 2017b). As Waisbord (2019) noted, "populism exhibits what communication scholars call 'the hostile media' phenomenon--the perception that the media are biased against one's convictions and ideological preferences" (p. 224). (The rise of fake news can also be interpreted as an instance of this phenomenon). In the case of Latin America, this can be envisioned as part of the complicated attempts of media reform that unfolded at the turn of the century in the region and continued over the 2010 s decade. CamposDomínguez (2017) summarizes findings of the particularities of populist communication on social media in Latin America: "instead of engaging with citizens to exchange views and listen to their ideas, populists have used Twitter to criticize critics, conduct personal battles and get the 
attention of the media" (p. 786). For this reason, she concluded that the populist communication style in Latin America is not unlike in other parts of the world.

Based on these findings, most scholars who have conducted empirical research tend to be cautious about the alleged promises of social media for communicating "directly" with "the people". Waisbord and Amado (2017) concluded that:

The promises of Latin American populism to overhaul the structure and dynamics of public communication ring hollow. Not only populism's top-down use of Twitter does not fit its grand vision of transforming communicative practices. Also, the way populist presidents use Twitter is not essentially different from the "hegemonic" political communication style they often criticize. (p. 1342)

In a similar manner, Moffitt $(2019,31)$ considered most ideas associated with the revolutionary potential of social media as analytical "traps" and warned against turning these assumptions into "common wisdom." He argued that these traps operate under a series of confusions: “(1) mistaking directness for being 'in touch' with 'the people'; (2) fetishising the 'unmediated' nature of populism [...] (3) assuming that populist online communication is multidirectional and (4) assuming that populist use of social media is relatively uniform" (Moffitt, 2019, 31). A more generalized conclusion in this body of work is that additional comparative and longitudinal data are needed to establish causal relationships between social media and the rise or spread of populism (Waisbord, 2019).

\section{"Fake News," Populism, and Religion}

Studying Fake News in Latin America 
More recently, researchers have turned their attention to the links between populism and misinformation (in the form of fake news and other types of content). Compared to other regions in the world, relatively little has been written about fake news in Latin America. In a literature review on the topic, Blanco Alfonso, García Galera and Tejedor Calvo (2019) found only two out of 172 publications between January 2012 and April 2019 about Latin American (specifically Chile and Mexico). A search conducted for this chapter in several academic databases yielded more results. We found at least 30 articles published in Latin America between 2017 and 2019 containing the term "noticias falsas" (fake news). This body of work seems to be growing over the years: in our sample, only two publications were from 2017, twelve were published in 2018 , and sixteen in 2019. These studies were unequally distributed by country: thirteen publications were about Brazil, five about Mexico, four about Venezuela, three Argentina and Chile (each), and two about Colombia. ${ }^{2}$

Researchers have covered a variety of issues in their writings about fake news. Several articles offer major reflections on the problem (Morales Campos, 2018). Many seek to find solutions to the spread of fake news, either through media literacy initiatives (Freire França, Furlan Costa \& Oliviera dos Santos, 2019); by discussing overall trends in news consumption and distribution (Montero-Liberona \& Halpern, 2019); or by emphasizing the gains of factchecking projects (Sánchez, 2019).

Because of their significance in regional studies about fake news, fact-checking initiatives deserve a closer look. Sánchez (2019) argued that data verification platforms in the region "followed the steps of the Argentinian Chequeado, a founding model in the continent in 2010" (p. 101). Since then, she noted, similar initiatives have emerged: Detector de Mentiras and

\footnotetext{
${ }^{2}$ We refer to articles about cases in each country, published in that country or published by academics associated with universities in that country.
} 
ColombiaCheck in Colombia; Truco, Agência Lupa, Aos Fatos and Agência Pública in Brazil; El Sabueso and ChecaDatos.mx in Mexico, and Con pruebas in Guatemala. For Sánchez (2019), the growth of such initiatives in Latin America has stabilized over the past years, considering that "in February 2018, there were 15 [Latin American projects] out of 149 active initiatives worldwide, a significant increase given that in 2014 there were only three” (p. 101). Sánchez examined the Mexican Verificado18, a collaborative initiative that was born in the wake of the July 2018 elections and which brought together more than sixty organizations, including media outlets, universities, and foundations from around the country.

The circulation of fake news has been linked to major social and political events in many countries of the region, notably presidential elections. Most articles have addressed countryspecific cases and, although populism is not their main focus, most examples are related to Latin American politicians who have typically been labeled as populists. Thus, in the case of articles about Venezuela, some were specifically about Hugo Chávez (Kitzberger, 2018) or about issues of immigration between Venezuela and Colombia (Ordóñez \& Ramírez Arcos, 2019). In the cases of Mexico and Brazil, articles dealt mostly with the controversial electoral processes of 2018 won by Manuel Andrés López Obrador (Álvarez Monsivais, 2018; Meyenberg Leycegui, 2018) and Jair Bolsonaro (e.g., Rezende, 2018; Stefanoni, 2018), respectively.

Although not strictly academic studies, surveys and public opinion polls also shed light on the broader socio-political context that surrounds the discussion of misinformation and fake news in Latin America. Data from the Latinobarómetro (2018) report warns about the fragility of democratic regimes in the region: although support for authoritarian governments remains relatively stable (15\%), there is a growing dissatisfaction with and indifference toward politics. Data also show that party affiliations continue to decline. This partially facilitates the emergence 
of populist and anti-system candidates from both the right and the left (such as López Obrador in Mexico and Bolsonaro in Brazil) and is a breeding ground for the spread of the strongly emotional content that characterizes fake news.

The Latin American Communication Monitor (2018-2019), which surveyed 1,229 communication managers in 19 countries in the region, found that most professionals in this field (62.5\%) pay attention to fake news and are convinced that these shape the public sphere at the national level (62.7\%). In their view, fake news come mostly from social media $(83.8 \%)$ and media outlets (37.8\%). Furthermore, $61.6 \%$ of communication managers in government organizations and $45 \%$ of them in companies indicated that fake news had affected their organization once or on several occasions, and the countries they felt were most affected by this were Dominican Republic, Colombia, and Costa Rica.

\section{Misinformation and Messianic Populism in Latin America}

Only a few scholars have addressed specifically the link between populism and misinformation in the region. Waisbord (2018) argued that present conditions in public communication are ideal for the proliferation of populist politics (which is intrinsically oriented towards post-truth). In his words, "the upsurge of populist politics is symptomatic of the consolidation of post-truth communication as a distinctive feature of contemporary politics" (Waisbord, 2018a, 18).

Waisbord drew on Weber's notion of "elective affinity" to suggest that there are key links between populism and post-truth, a relationship that "should not be mechanistically viewed as straightforward causation, but rather in terms of similarities, analogies, convergence, and/or reinforcement between social facts such as culture, politics, religion, and economics" (Waisbord, 
2018a, 18). In his view, two processes have led to this particular situation: the breakdown of the legacy media order and the increasing fragmentation of mediated spheres. From this perspective, the spread of misinformation both results from and empowers populism

Building on Waisbord's analysis, we argue that religion has become a third key component of the elective affinity between populism and post-truth in the particular case of Latin America. Laclau's (2005) approach to populism is a key to make this argument. According to Laclau (2005), populism is not best defined by its political or ideological contents, but rather by "a particular logic of articulation" that builds on discourses that dichotomize social spaces and collective identities (p. 32). As a result, populism emerges whenever social events are framed in terms of a dichotomous border that separates "those above" (us) from "those below" (them) (Laclau, 1987, 30).

The dichotomous nature of populism holds important affinities with the discourse of Western religions. In the particular context of Latin America, this has been the case since colonial times. To this day, Catholicism has privileged a discourse that separates it from "the people" through a binary that overlaps with the political realm, causing a dichotomy that hinders pluralism and diversity while fostering social polarization. In this context, certain political ideologies have acquired almost the status of religious doctrines, such as Peronism in Argentina (Mansilla, 2012).

Extending forms of authority that prevailed at the turn of the century (which emphasized the idea of the hero who came to rescue "the people"), populism in Latin America has acquired a much more explicitly religious expression (which stresses the role of messiahs in saving "the people" from certain threats). This allows establishing another link with the work of Weber, who studied the mechanisms of charismatic authority (in ways that tied together both political and 
religious realms). According to Weber (2013), charismatic authority is messianic in nature. In his words,

The turning point is always the same: charismatic men and [their] disciples become companions admitted to the Lord's table and endowed with special and distinctive rights [...] The dominated of the charismatic structure [...] become "subjects" submitted [...] to the coercion and discipline of a rule and an order, or even "citizens" obeying the law. The charismatic message inevitably becomes [...] dogma, doctrine, theory, regulation, legal code or content of a tradition that gets petrified. (Weber, 2013, 465-466)

Although the articulation or elective affinity between populism and religion dates back to pre-democratic times, it prevails in many democratic systems in Latin America. The binary essence of this discourse remains, but it has also varied in two important ways: (1) the nature of its manifestations (given the prevalence of fake news and misinformation issues); and (2) the institutional source of religious discourse (given that Catholicism is no longer the sole religious denomination that fuels populist rhetoric in the region). In what follows, we discuss these two issues in their relationship to issues of misinformation.

Framing religion as part of the elective affinity between populism and post-truth helps understanding some of the particular manifestations that this link has acquired in Latin America over the past years. Recent presidential campaigns in various countries of the region show how this tripartite affinity has manifested in the parallel dissemination of particular kinds of content, served as a platform for the rise of populist political/religious figures, and shaped the outcome of electoral processes. For example, Guevara (2020) and Siles, Carazo and Tristán (2020) demonstrated that, during the presidential elections that took place in 2018 in Brazil, Costa Rica, 
and Mexico, social media fueled a polarization of the electorate regarding topics such as sexual orientation and social values.

The combination of misinformation, populist styles of communication, and religious discourses has been a fertile ground for the rise of political/religious candidates and politicians from neo-pentecostal churches. The cases of Jair Bolsonaro in Brazil and Fabricio Alvarado in Costa Rica (not to be confused with Carlos Alvarado, the country's president) exemplify how the rise of the neo-pentecostal and evangelical churches have added nuance and complexity to the fight between multiple actors and movements for the "populist reason" in Latin America (c.f. Laclau, 2005). Key in this process is the construction of a discursive premise that separates $u s$ from them, which is framed around the distinction between traditional values and new threats. This elective affinity enacted a form of symbolic violence that was crucial for understanding not only the results of these elections but also how they unfolded (Guevara 2020; Siles, 2020).

In this context, the Bible has become a key component of the populist communications kit in Latin America: along with Brazil national soccer team's jersey, it was the central symbol of Jair Bolsonaro's discursive fight against "the red flag, 'gender ideology' and corruption" (Stefanoni, 2018); El Salvador's Nayib Bukele carried it with him during his inauguration; and like many other presidents in the region, Guatemala's Jimmy Morales cited it as the main weapon to stop the "battle" against the COVID-19 "enemy". It is not that surprising that, after the resignation of Evo Morales in November of 2019, Jeanine Añez, the self-proclaimed president who took over the country's government, declared: "The Bible returns to the Palace" after entering the Palacio de Gobierno in La Paz, Bolivia on November 12, 2019.

Social media platforms and apps such as Facebook, Twitter, and WhatsApp are crucial in the creation of an "epistemic democracy" (Waisbord, 2018b, 1870) where journalistic values and 
populist/messianic discourses compete for the attention of digital communities. These constitute “communities of belief", as Waisbord (2018b) calls them, and are "anchored by common allegiance to politics, ideology, and religion as well as socio-demographic variables" (p. 1870). Both in form and in substance, Bukele's speech at the United Nations General Assembly--where he snapped a selfie and positioned himself as a model in the political use of social media platforms for connecting with "the people" in El Salvador--illustrates this phenomenon.

The relationship between populism, misinformation, and religion in Latin America is a threat to democracy and human rights. This is because the separation from us and them that underlies the populist/religious reason, often exploited by and reinforced through fake news, creates political scenarios in which certain groups are banned from expanding their rights or, even worse, losing rights that they had already acquired. Human Rights Watch's (HRW) director, Kenneth Roth, warned that the government of Jair Bolsonaro attacks human rights by using repeatedly excessive force against civil society and the media. In a similar manner, in the past Costa Rican election, Fabricio Alvarado, a candidate from the neo-pentecostal political party Restauración Nacional, helped define the central media event of the campaign around the issue of "gay marriage". This not only polarized the election but also excluded other relevant topics from the democratic debate (Siles, 2020; Siles, Carazo \& Tristán, 2020).

\section{Concluding Remarks}

This chapter examined how researchers have studied issues of populism, media, and misinformation in Latin America. Populism in the region has shared important characteristics with other expressions of this phenomenon around the world. Both at present and in the past, populist figures have emerged at both ends of the political spectrum. Yet populism has also 
shown specific regional features, such as its historical relationship with religious discourses that privilege a binary form of thinking. We conclude this chapter by noting some opportunities for future research in order to make visible both the similarities and differences in the study of populism and misinformation in Latin America and other parts of the world.

As noted in the first part of this essay, researchers have been interested in identifying the main features of the populist communications kit in Latin America. There has been a longstanding interest in understanding how political figures have variously used media and communications (from legacy media to Internet technologies) to materialize populist discourses. This has resulted in valuable knowledge about how certain communication styles and techniques have emerged and evolved over time in the region. However, a discussion of the implications of the populist communications kit has not always accompanied these studies. There is still a dearth of research that discusses exactly why populist communication approaches are troubling for democracy and human rights in Latin America, given the region's history and political specificities.

Despite the interest in the production of populist discourses, issues of reception have not received comparable attention. Only a handful of studies have empirically investigated how audiences and publics relate to, incorporate, or resist populist messages (Berjaud, 2016). The same could be said about fake news. Not much is known about how people interpret this kind of information and how they seek to authenticate it (that is, if they do). Understanding how and why populist discourse interpellates specific communities (both online and offline) could help address this void and thus broaden our understanding of how "epistemic democracies" function.

Waisbord's (2018a) argument about the "elective affinity" between populism and posttruth offers a fruitful avenue for understanding the spread of fake news in the region. Further 
studies could empirically verify how this argument applies to the particular case of Latin America. Has this elective affinity shown signs of cultural specificity? For example, Waisbord (2018) provided only a brief account of the similarities between Hugo Chávez's and Donald Trump's discourses. In this chapter, we argued that religion has become a major component of this elective affinity in many countries of the region. Research could elaborate how this argument compares to other parts of the world.

Finally, there is a lack of comparative research in the region that goes beyond the use of statistics for illustrative purposes. Although not specifically about populism, Guevara's (2020) study of the role of social media in the electoral processes in Brazil, Colombia, Costa Rica, and Mexico shows the promises of this form of analysis in that it helps identify the main patterns of similarity and difference that cut across the region. Guevara (2020) thus showed what polarization looks like in these particular countries, and what theoretical and methodological challenges are involved in studies conducted at a regional level. In this way, comparative research provides fruitful analytical lenses to understand the links between populism, misinformation, and religion in Latin America.

\section{Acknowledgement}

We thank Erica Guevara for her most helpful suggestions about previous versions of this chapter.

\section{References}

Álvarez Monsiváis, E. (2018). ¿Quién ganó el debate en el Estado de México? Las encuestas en Twitter como síntoma de posverdad. Virtualis, 8(16), 4-29.

Berjaud, C. (2016). Cinq sur cinq, mi Comandante! Contribution à l'étude des réceptions des 
discours politiques télévisés. Paris: Éditions Dalloz.

Blanco Alfonso, I., García Galera, C., y Tejedor Calvo, S. (2019). El impacto de las fake news en la investigación en Ciencias Sociales. Revisión bibliográfica sistematizada. Historia y Comunicación Social, 24(2), 449-469.

Boas, T. C. (2005). Television and neopopulism in Latin America: Media effects in Brazil and Peru. Latin American Research Review, 40(2), 27-49.

Campos-Domínguez, E. (2017). Twitter y la comunicación política. El Profesional de la Información, 26(5), 785-793.

De la Torre, C. (2000). Populist seduction in Latin America: The Ecuadorian experience. Athens: Ohio University Press.

De la Torre, C. (2013). El tecnopopulismo de Rafael Correa: ¿Es compatible el carisma con la tecnocracia? Latin American Research Review, 48(1), 24-43.

De la Torre, C. (2017). Hugo Chávez and the diffusion of Bolivarianism. Democratization, 24(7), 1271-1288.

Farias, A. (2018). Twitter and institutional change: Insights from populist and pluralist discourses in Venezuela. Potentia: Journal of International and Public Affairs, 9, 79-96.

Freire França, F., Furlan Costa, M. L., \& Oliviera dos Santos, R. (2019). As novas tecnologias de informação e comunicação no contexto educacional das políticas públicas. ETDEducação Temática Digital, 21(3), 645-661.

Guevara, E. (2020). Comentario: Redes sociales y “polarización”: una mirada comparada de las elecciones de 2018 en Brasil, Colombia, Costa Rica y México. In I. Siles (Ed.), Democracia en digital: Facebook, comunicación y política en Costa Rica (pp. 207-232). San José: CICOM. 
Guevara, E. (2012). "Téléprésidents” ou "média-activistes” de gauche? Argentine, Brésil, Venezuela, Colombie. In O. Dabène (Ed.), La Gauche en Amérique latine, 1998-2012 (pp. 105-144). Paris: Presses de Sciences Po.

Kitzberger, P. (2018). "Caimanes del mismo pozo”. Populismo y representaciones de los medios y la prensa en la estabilización hegemónica del chavismo. Revista Mexicana de Opinión Pública, 25, 15-38.

Latin American Communication Monitor (LCM 2018-2019). Retrieved from: http://latincommunicationmonitor.com/

Laclau, E. (2005). On Populist Reason. New York: Verso.

Mansilla, H. C. F. (2012). La religiosidad popular, las corrientes maniqueístas y la cultura política latinoamericana. El caso de las oposiciones binarias excluyentes. Reflexión Política, 14(27), 2-15.

Meyenberg Leycegui, Y. (2018). Votar en tiempos de cólera. Revista Mexicana de Sociología, $80(4), 947-954$.

Moffitt, B. (2019). Populism 2.0: Social media and the false allure of 'unmediated' representation. In G. Fitzi, J. Mackert, \& B. S. Turner (Eds.), Populism and the Crisis of Democracy (Vol. 2, pp. 30-46). New York: Routledge.

Montero-Liberona, C., \& Halpern, D. (2019). Factores que influyen en compartir noticias falsas de salud online. El Profesional de la Información, 28(3), 1-9.

Morales Campos, E. M. (2018). La posverdad y las noticias falsas: el uso ético de la información. México: UNAM.

Mudde, C. (2016). Europe's populist surge: A long time in the making. Foreign Affairs, 95(November/December), 25-30. 
Ordóñez, J. T., \& Ramírez Arcos, H. E.(2019). (Des) orden nacional: la construcción de la migración venezolana como una amenaza de salud y seguridad pública en Colombia. Revista Ciencias de la Salud, 17, 48-68.

Retamozo, Martín. (2006). La razón populista. Perfiles Latinoamericanos, 13(27), 253-258.

Rezende, R. (2018). Jair Bolsonaro, populismo de derecha y fin de ciclo político. Revista Política Latinoamericana, 7, 1-15.

Rincón, O. (2008). Introducción: ¿La comunicación no tiene ideología? In O. Rincón (Ed.), Los tele-presidentes: Cerca del pueblo, lejos de la democracia (pp. 5-13). Bogotá: Friedrich Ebert Stiftung.

Sánchez, A. N. (2019). Periodismo de confirmación vs. desinformación: Verificado18 y las elecciones mexicanas de 2019. Ámbitos. Revista Internacional de Comunicación, 43, 95114.

Siles, I. (Ed.). (2020). Democracia en digital: Facebook, comunicación y politica en Costa Rica. San José: CICOM.

Siles, I., Carazo, C. \& Tristán, L. (2020). El “matrimonio gay” como tema electoral en Costa Rica: eventos mediáticos en sistemas híbridos de comunicación. In I. Siles (Ed.), Democracia en digital: Facebook, comunicación y política en Costa Rica (pp. 207-232). San José: CICOM.

Siles, I., Espinoza, J., \& Méndez, A. (2019). La investigación sobre tecnología de comunicación en América Latina: Un análisis crítico de la literatura (2005-2015). Palabra Clave, 22(1).

Stefanoni, P. (2018). Biblia, buey y bala... recargados: Jair Bolsonaro, la ola conservadora en Brasil y América Latina. Nueva Sociedad, 278, 4. Retrieved from: https://nuso.org/articulo/biblia-buey-y-bala-ola-conservadora-brasil-bolsonaro-stefanoni/ 
Waisbord, S. (2014). Vox populista: Medios, periodismo, democracia. Barcelona: Gedisa.

Waisbord, S. (2018a). The elective affinity between post-truth communication and populist politics. Communication Research and Practice, 4(1), 17-34.

Waisbord, S. (2018b). Truth is what happens to news: On journalism, fake news, and post-truth. Journalism Studies, 19(13), 1866-1878.

Waisbord, S. (2019). Populism as media and communication phenomenon. In C. De la Torre (Ed.), Routledge handbook of global populism (pp. 221-234). New York: Routledge.

Waisbord, S., \& Amado, A. (2017). Populist communication by digital means: Presidential Twitter in Latin America. Information, Communication \& Society, 20(9), 1330-1346.

Weber, M. (2013). La transformation du charisme et le charisme de fonction. Revue Française de Science Politique, 63(3), 463-486.

Weyland, K. (2001). Clarifying a contested concept: Populism in the study of Latin American politics. Comparative Politics, 34(1), 1-22. 